\title{
Preparation of Blackened Ca-based Composite Particles and Their Carbonation Kinetics Features
}

\author{
Liang Teng ${ }^{1}$, Yimin XUAN ${ }^{1}$, Xianglei Liu ${ }^{1}$, and Yulong Ding ${ }^{2}$ \\ ${ }^{1}$ Nanjing University of Aeronautics and Astronautics \\ ${ }^{2}$ University of Birmingham
}

April 23, 2021

\begin{abstract}
The calcium looping thermochemical thermal energy storage is one of the best high-temperature heat storage schemes for 3th concentrating solar power photothermal power, but its application is restricted by the inherent low solar absorptance and poor cyclic stability of $\mathrm{CaCO} 3 / \mathrm{CaO}$. Herein, the solar absorptance of $\mathrm{CaCO} 3$ particles is enhanced by doping $\mathrm{Mn}-\mathrm{Fe}$ oxides, meanwhile, awns of setaria faberis and microcrystalline cellulose are used as bio-templates to generate pores inside the particles. The test results show that the prepared particles possess adequate anti-crushing strength, high cyclic stability, high solar absorption, and high carbonation rate. In addition, the carbonation kinetic equation of the composite porous particles is studied with the influence factors such as $\mathrm{CO} 2$ partial pressure, reaction temperature, and particle morphology taken into consideration. is of great significance for the design and regulation of the carbonator achieving highly stable heat output in the CaL thermochemical heat storage system.
\end{abstract}

\section{Hosted file}

Highlights .pdf available at https ://authorea.com/users/409550/articles/519174-preparation-ofblackened-ca-based-composite-particles-and-their-carbonation-kinetics-features

\section{Hosted file}

Manuscript .pdf available at https ://authorea.com/users/409550/articles/519174-preparation-ofblackened-ca-based-composite-particles-and-their-carbonation-kinetics-features

\section{Hosted file}

Declaration of Interest Statement.pdf available at https://authorea.com/users/409550/ articles/519174-preparation-of-blackened-ca-based-composite-particles-and-theircarbonation-kinetics-features 